\title{
Cranial and extracranial giant cell arteritis do not have different HLA-DRB1 and HLA-B association in Caucasian individuals
}

\author{
Diana Prieto-Peña $\left.{ }^{1,2^{*}} \mathbb{(}\right)$, Sara Remuzgo-Martínez ${ }^{2}$, Belén Atienza-Mateo ${ }^{1,2}$, Raquel López-Mejias ${ }^{2}$ and \\ Miguel Á. González-Gay ${ }^{1,2,3,4}$ on behalf of the Spanish collaborative group for the study of large-vessel \\ vasculitis
}

To the editor,

We have read with interest the article published in Arthritis Research \& Therapy by Kushimoto et al. suggesting that the $H L A-B * 52$ allele may indicate the presence of diffuse extracranial large vessel vasculitis (LVV) in patients with giant cell arteritis (GCA) [1]. GCA is the prototype of LVV that affects people over 50 years of age, especially those of European descent [2]. Unlike Takayasu arteritis, a LVV that predominantly affects people under 50 years of age, GCA is rare in Asian countries [3]. For years, GCA was considered a cranial disease. However, the use of imaging techniques has shown that it also affects large extracranial vessels [4]. In this sense, in some cases, GCA has a pure extracranial phenotype. These patients are usually younger and have polymyalgia rheumatica (PMR) more frequently than those with a classic pattern of cranial GCA [5].

There is a genetic component in the pathogenesis of GCA [6]. Different studies point to the influence of genes located in the MHC region, in particular the $H L A$ $D R B 1$ *04 alleles [7]. Since the pattern of vascular involvement in Takayasu arteritis often resembles that found in patients with extracranial GCA, and the genetic contribution to the pathogenesis of the disease is mainly mediated by the $H L A-B * 52$ allele [8], we wondered if

*Correspondence: diana.prieto.pena@gmail.com

${ }^{1}$ Department of Rheumatology, Hospital Universitario Marqués de Valdecilla, Avenida Cardenal Herrera Oria s/n, 39011 Santander, Spain

Full list of author information is available at the end of the article in Caucasian individuals the association of HLA with GCA may differ according to the predominant pattern of the disease. For this reason, we evaluated a series of 105 Spanish patients older than 50 years with extracranial LVV without cranial manifestations and compared them with a series of 184 patients with biopsy-proven GCA with typical cranial manifestations of the disease, who did not present features of extracranial involvement. We confirmed in our population the previously reported association of GCA with $H L A-D R B 1^{*} 04$, in particular with the HLA-DRB1*04:01 allele, regardless of the clinical phenotype [9]. In a further step, we looked for possible differences in the $H L A-B$ locus. However, we did not find $H L A-B$ differences between these two subgroups of Spanish patients with GCA that showed a similar association with the $H L A-B^{*} 15$ allele, mainly due to $H L A$ $B^{*} 15: 01$. Furthermore, we found that the presence of $H L A-B * 15: 01$ and $H L A-D R B 1 * 04: 01$ increases the risk of developing both cranial and extracranial LVV-GCA in our population [10].

Kushimoto et al. evaluated 40 Japanese patients over 50 years of age who were categorized as elderly-onset LVV (EOLVV) that showed diffuse vascular lesions similar to those found in extracranial LVV-GCA, 13 of them also had temporal artery involvement, while 27 did not [1]. The 27 patients with isolated extracranial EOLVV were classified into two groups: 11 and 16 patients with and without PMR. The 11 extracranial EOLVV patients with PMR and the 13 patients with both cranial and extracranial involvement formed a cluster of patients who were 
$H L A-B * 52$ positive [1]. However, we could not demonstrate a higher prevalence of the $H L A-B * 52$ allele in Spanish patients with extracranial GCA [10]. In this regard, only 2 of 105 Spanish patients with extracranial-LVV carried the $H L A-B * 52$ allele. This frequency was similar to that observed in patients with cranial GCA (4 of 184) and healthy controls (15 of 486). Accordingly, $H L A-B * 52$ cannot be considered as a marker for extracranial LVV in Caucasian individuals over 50 years of age.

It is possible that different genetic backgrounds and the influence of other genes located outside the MHC region may explain the differences in the incidence and clinical expression of LVV in Caucasian individuals compared to those in Asian countries.

\section{Abbreviations}

GCA: Giant cell arteritis; LW: Large vessel vasculitis; PMR: Polymyalgia rheumatica.

\section{Acknowledgements}

Spanish collaborative group for the study of large-vessel vasculitis: Fernanda Genrea, Javier Gonzalo Ocejo-Vinyals', Alejandro Muñoz Jiménez ${ }^{\mathrm{c}}$, Francisco Ortiz-Sanjuán ${ }^{d}$, Susana Romero-Yuste ${ }^{\mathrm{e}}$, Clara Moriano ${ }^{f}$, Eva Galíndez-Agirregoikoa ${ }^{9}$, Itziar Calvo ${ }^{g}$, Norberto Ortego-Centeno ${ }^{\text {h }}$, Noelia Álvarez-Rivasi', José A. Miranda-Filloyj, Irene Llorente ${ }^{k}$, Ricardo Blanco ${ }^{a, l}$, Oreste Gualillo ${ }^{m, n}$, Javier Martín ${ }^{\circ}$, Ana Márquez ${ }^{\circ}$, Santos Castañeda ${ }^{k}$, Iván Ferraz-Amaro ${ }^{p}$

aResearch group on genetic epidemiology and atherosclerosis in systemic diseases and in metabolic bone diseases of the musculoskeletal system, IDIVAL, Santander, Spain.

${ }^{b}$ Department of Immunology, Hospital Universitario Marqués de Valdecilla, Santander, Spain.

'Department of Rheumatology, Hospital Universitario Virgen del Rocío, Sevilla, Spain.

${ }^{d}$ Department of Rheumatology, Hospital Universitario y Politécnico La Fe, Valencia, Spain.

eDepartment of Rheumatology, Complejo Hospitalario Universitario Pontevedra, Spain

fDepartment of Rheumatology, Complejo Asistencial Universitario de León, León, Spain. Spain.

${ }^{9}$ Department of Rheumatology, Hospital Universitario de Basurto, Bilbao,

${ }^{\text {h} A u t o i m m u n e ~ D i s e a s e s ~ U n i t, ~ H o s p i t a l ~ U n i v e r s i t a r i o ~ S a n ~ C e c i l i o, ~ I n s t i t u t o ~ d e ~}$ Investigación Biosanitaria de Granada (IBS Granada), Department of Internal Medicine, University of Granada, Granada, Spain.

iDepartment of Rheumatology, Hospital Universitario San Agustín, Avilés, Spain. Spain.

'Division of Rheumatology, Hospital Universitario Lucus Augusti, Lugo,

${ }^{\mathrm{k}}$ Department of Rheumatology, Hospital Universitario de la Princesa, IIS-Princesa, Cátedra EPID Future, Universidad Autónoma de Madrid (UAM), Madrid, Spain.

'Department of Rheumatology, Hospital Universitario Marqués de Valdecilla, Santander, Spain.

mHealth Research Institute of Santiago, Santiago de Compostela, Spain.

"The NEIRID Group (Neuroendocrine Interactions in Rheumatology and Inflammatory Diseases), Santiago University Clinical Hospital, Santiago de Compostela, Spain.

OInstituto de Parasitología y Biomedicina 'López-Neyra', CSIC, PTS Granada, Granada, Spain. Spain.

PDivision of Rheumatology, Hospital Universitario de Canarias, Tenerife,

\section{Authors' contributions}

DP-P and MAG-G designed the work, analyzed and interpreted the data, and were major contributors in writing the manuscript. SR-M and RL-M performed the genotyping analysis, analyzed the data, and revised the manuscript. BA-M was a major contributor in recruiting patients and made substantial contributions to the conception of the work. All authors read and approved the final manuscript.

\section{Funding}

This research did not receive any specific grant from funding agencies in the commercial or not-for-profit sectors.

DP-P is supported by a research contract from the Carlos III Health Institute of Spain (Rio Hortega program, ref. CM20/00006). SR-M is supported by funds of the RETICS Program (RD16/0012/0009), co-founded by the European Regional Development Fund (ERDF). BA-M is a recipient of a "López-Albo" Post-Residency Programme funded by Servicio Cantabro de Salud. OG is staff personnel of Xunta de Galicia (Servizo Galego de Saude [SERGAS]) through a research-staff stabilization contract (ISCIII/SERGAS), and his work is funded by ISCIII and the European Union FEDER fund (grants RD16/0012/0014 [RIER] and $\mathrm{PI} 17 / 00409)$. He is the beneficiary of project funds from the Research Executive Agency (REA) of the European Union in the framework of MSCA-RISE Action of the H2020 Programme, project 734899-Olive-Net. RL-M is a recipient of a Miguel Servet type I programme fellowship from the "Instituto de Salud Carlos III" (ISCIII), co-funded by the European Social Fund (ESF, "Investing in your future") (grant CP16/00033).

\section{Availability of data and materials}

All data generated or analyzed during this study are included in this published article.

\section{Declarations}

\section{Ethics approval and consent to participate}

The study was approved by the Ethics Committee of clinical research of Cantabria for Hospital Universitario Marqués de Valdecilla, of Bilbao for Hospital Universitario de Basurto (Bilbao, Spain), of León for Hospital de León, of Madrid for Hospital Universitario de La Princesa, of Valencia for Hospital Universitario y Politécnico La Fe, of Sevilla for Hospital Universitario Virgen del Rocío, of Pontevedra for Hospital Universitario de Pontevedra, of Lugo for Hospital Universitario Lucus Augusti, of Granada for Hospital Universitario San Cecilio, and of Avilés for Hospital San Agustín. All subjects provided informed written consent before being enrolled in the study. The procedures followed were in accordance with the ethical standards of the approved guidelines and regulations, according to the Declaration of Helsinki.

\section{Consent for publication}

Not applicable.

\section{Competing interests}

DP-P has received research support from UCB Pharma, Roche, AbbVie, and Lilly. BA-M received grants/research supports from Kern Pharma, AbbVie, Pfizer, Celgene, and GSK. RB received grants/research supports from Abbvie, MSD, and Roche and had consultation fees/participation in companysponsored speaker's bureau from Abbvie, Lilly, Pfizer, Roche, Bristol-Myers, Janssen, UCB Pharma, and MSD. MAG-G received grants/research supports from Abbvie, MSD, Jansen, and Roche and had consultation fees/participation in company-sponsored speaker's bureau from Abbvie, Pfizer, Roche, Sanofi, Lilly, Celgene, and MSD. The remaining authors declare that they have no competing interests.

\section{Author details}

${ }^{1}$ Department of Rheumatology, Hospital Universitario Marqués de Valdecilla, Avenida Cardenal Herrera Oria s/n, 39011 Santander, Spain. ${ }^{2}$ Research group on genetic epidemiology and atherosclerosis in systemic diseases and in metabolic bone diseases of the musculoskeletal system, IDIVAL, Santander, Spain. ${ }^{3}$ School of Medicine, Universidad de Cantabria, Santander, Spain. ${ }^{4}$ Cardiovascular Pathophysiology and Genomics Research Unit, School of Physiology, Faculty of Health Sciences, University of the Witwatersrand, Johannesburg, South Africa.

Received: 4 October 2021 Accepted: 15 October 2021

Published online: 26 October 2021 


\section{References}

1. Kushimoto K, Ayano M, Nishimura K, Nakano M, Kimoto Y, Mitoma H, et al. H. HLA-B52 allele in giant cell arteritis may indicate diffuse large-vessel vasculitis formation: a retrospective study. Arthritis Res Ther. 2021;23:238.

2. Gonzalez-Gay MA, Vazquez-Rodriguez TR, Lopez-Diaz MJ, Miranda-Filloy JA, Gonzalez-Juanatey C, Martin J, et al. Epidemiology of giant cell arteritis and polymyalgia rheumatica. Arthritis Rheum. 2009;61:1454-61.

3. González-Gay MA, García-Porrúa C. Epidemiology of the vasculitides. Rheum Dis Clin North Am. 2001;27:729-49.

4. González-Gay MA, Prieto-Peña D, Calderón-Goercke M, Atienza-Mateo B, Castañeda S. Giant cell arteritis: more than a cranial disease. Clin Exp Rheumatol. 2020;38(Suppl 124):15-7.

5. González-Gay MA, Prieto-Peña D, Martínez-Rodríguez I, Calderon-Goercke M, Banzo I, Blanco R, et al. Early large vessel systemic vasculitis in adults. Best Pract Res Clin Rheumatol. 2019;33:101424.

6. Carmona FD, González-Gay MA, Martín J. Genetic component of giant cell arteritis. Rheumatology (Oxford). 2014;53:6-18.
7. Carmona FD, Mackie SL, Martín JE, Taylor JC, Vaglio A, Eyre S, et al. Am J Hum Genet. 2015;96:565-80.

8. Saruhan-Direskeneli G, Hughes T, Aksu K, Keser G, Coit P, Aydin SZ, et al. Identification of multiple genetic susceptibility loci in Takayasu arteritis. Am J Hum Genet. 2013;93:298-305.

9. Prieto-Peña D, Remuzgo-Martínez S, Ocejo-Vinyals JG, Atienza-Mateo B, Muñoz-Jiménez A, Ortiz-Sanjuán F, et al. Cranial and extracranial giant cell arteritis share similar HLA-DRB1 association. Semin Arthritis Rheum. 2020;50:897-901.

10. Prieto-Peña D, Remuzgo-Martínez S, Ocejo-Vinyals JG, Atienza-Mateo B, Genre F, Muñoz-Jimenez A, et al. Clin Exp Rheumatol. 2021;39(Suppl 129):21-6.

\section{Publisher's Note}

Springer Nature remains neutral with regard to jurisdictional claims in published maps and institutional affiliations.
Ready to submit your research? Choose BMC and benefit from:

- fast, convenient online submission

- thorough peer review by experienced researchers in your field

- rapid publication on acceptance

- support for research data, including large and complex data types

- gold Open Access which fosters wider collaboration and increased citations

- maximum visibility for your research: over 100M website views per year

At BMC, research is always in progress.

Learn more biomedcentral.com/submissions 